ANL-5951

Metallurgy and Ceramics (TID-4500, 14th Ed.)

AEC Research and

Development Report

ARGONNE NATIONAL LABORATORY

P. O. Box 299

Lemont, Ellinois

INSPECTION OF FUEL ELEMENT COMPONENTS AND FUEL

ELEMENTS FOR THE ARGONNE LOW POWER REACTOR

By

W. J. McGonnagle, W. N. Beck, and N. Lapinski

Program 7.6.8

Portions of the material appearing in this report appeared in the following Metallurgy Division Report:

Report No. Section Date

ANL-5837 Item IV 1 December 1957

August 1959

Operated by The University of Chicago

under

Contract $W-31-109-$ eng-38 


\section{DISCLAIMER}

This report was prepared as an account of work sponsored by an agency of the United States Government. Neither the United States Government nor any agency Thereof, nor any of their employees, makes any warranty, express or implied, or assumes any legal liability or responsibility for the accuracy, completeness, or usefulness of any information, apparatus, product, or process disclosed, or represents that its use would not infringe privately owned rights. Reference herein to any specific commercial product, process, or service by trade name, trademark, manufacturer, or otherwise does not necessarily constitute or imply its endorsement, recommendation, or favoring by the United States Government or any agency thereof. The views and opinions of authors expressed herein do not necessarily state or reflect those of the United States Government or any agency thereof. 


\section{DISCLAIMER}

Portions of this document may be illegible in electronic image products. Images are produced from the best available original document. 


\section{TABLE OF CONTENTS}

$\underline{\text { Page }}$

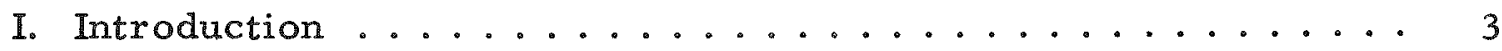

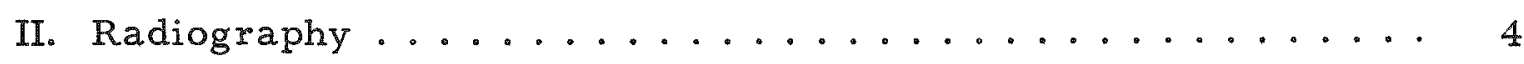

A. Core Blanks ....................... 4

B. Fuel Plates before Shearing .............. 4

C. Fuel Elements after Bending. ............. 4

III Ultrasonic Testing ....................

A. Core Blanks......................... 5

B. Cladding Stock ................... 5

c. Bond Test ............................ 5

IV. Gamma Scintillation Counting............... 5

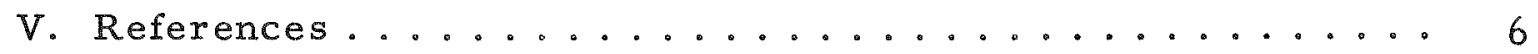




\title{
INSPECTION OF FUEL ELEMENT COMPONENTS AND FUEL ELEMENTS FOR THE ARGONNE LOW POWER REACTOR
}

\author{
by
}

\author{
W. J. McGonnagle, W. N. Beck, and N. Lapinski
}

\section{INTRODUCTION}

The Argonne Low Power Reactor (ALPR) is a direct-cycle boiling water reactor, using enriched uranium fuel and moderated and cooled by the natural circulation of light water. ALPR is designed to produce 3000 kilowatts of gross reactor heat. The core material is U-235 in the form of an alloy containing $80.5 \mathrm{w} / \mathrm{o}$ aluminum, $17.5 \mathrm{w} / \mathrm{o}$ uranium and $2 \mathrm{w} / \mathrm{o}$ nickel.

There were approximately 40 grams of U-235 per core blank. The cladding material was X8001 aluminum alloy. The core and clad were bonded by means of a silicon pressure-bonding technique.

The finished plates were 27.8 inches long, 4.6 inches wide and 0.120 inch thick. Details concerning the fabrication of the fuel and fuel components can be found in the following reports:

ANL-5950 - "Development and Production of Core Material for ALPR Fuel Elements," R. E. Macherey, R. L. Salley and $W . R . B u r t, J r$. (to be is sued)

\section{ANL-5965 - "Manufacture of Fuel Plates and Fuel Subassemblies for the Argonne Low Power Reactor," R. A. Noland, D. E. Walker, and M. M. Martin (to be is sued)}

Three nondestructive testing techniques were used in inspecting the ALPR fuel elements and fuel element components: radiography, ultrasonic transmission and gamma scintillation countung. Radiography was used to inspect the alloy cores, the rolled fuel elements before shearing and the fuel plates after bending. The ultrasonic transmission was used to inspect the alloy cores, the cladding stock and the finished fuel elements. Gamma scintillation counting was used to determine the $U-235$ content in the fuel element core blanks. 


\section{RADIOGRAPHY}

\section{A. Core Blanks}

Radiographs were made of all ALPR fuel element core blanks, which had the following dimensions: length - 6.875 inches; width -3.31 inches; thickness - $0.200 \mathrm{inch}$. The radiographs were made under the following conditions:

$\begin{array}{ll}\text { Kilovoltage } & -250 \\ \text { Source to film distance } & -48 \text { inches } \\ \text { Exposure } & -550 \text { milliampere seconds } \\ \text { Film type } & - \text { Kodak AA }\end{array}$

Six core blanks were radiographed in each 14 inch $\mathrm{x} 17$ inch film. The cores were arranged on the film in the same order that they were punched out of the alloy sheet. Thus, if radiographs were laid out in order, they would make a record of the sheet. A penetrometer made from core alloy was used. A penetrometer sensitivity of 2 per cent was obtained. A total of 1150 cores were radiographed. One hundred thirty-two cores were rejected because of inhomogeneities in the alloy.

B. Fuel Plates before Shearing

Radiographs were made of all ALPR fuel elements after rolling and before shearing. The ends of two fuel elements were radiographed on each 14 inch $\times 17$ inch film. Two radiographs were made per fuel plate. Radiographs were made under the following conditions:

$\begin{array}{ll}\text { Kilovoltage } & -70 \\ \text { Source to film distance } & -48 \text { inches } \\ \text { Exposure } & -100 \text { milliampere seconds } \\ \text { Film type } & \text { - Ansco Super A }\end{array}$

Sensitivity was of no primary concern in these radiographs because the radiographs were used only as a guide in the shearing operation.

\section{Fuel Elements after Bending}

Radiographs were made of all fuel elements after the bending oper ation. This was done to determine the amount of clad material remaining between the core and the bent portion of the fuel element. Radiographs were made under the following conditions:

$\begin{array}{ll}\text { Kilovoltage } & -95 \\ \text { Source to film distance } & -48 \text { inches } \\ \text { Exposure } & -125 \text { milliampere seconds } \\ \text { Film type } & - \text { Ansco Super A }\end{array}$


Three fuel elements were placed on each 14 inch $\times 17$ inch film. The middle 17 inches of the fuel element was the only section radiographed. Sensitivity was of no primary concern in radiographing the 675 bent fuel elements. Twenty fuel elements were rejected for not having sufficient side clad.

\section{ULTRASONIC TESTING}

An ultrasonic transmission technique was used for inspecting the alloy core blanks, the aluminum cladding stock and the finished fuel elements. A frequency of 1 megacycle was used in testing all the specimens. Electrosensitive paper recordings were made of all specimens. Details of the ultrasonic transmission technique and the scanning equipment are described in ANL-5653.(1)

\section{A. Core Blanks}

Seven hundred twenty-six core blanks were inspected by the ultrasonic transmission technique. Ninety-two were rejected for various kinds of flaws.

B. Cladding Stock

A large percentage of the X8001 alloy cladding stock was inspected for laminations and other flaws. Considerable material was found unacceptable for reactor use by this technique.

\section{Bond Test}

A total of 675 ALPR fuel plates were ultrasonically tested for bond. Unbonded areas were found in 111 of the plates. Any unbonded area greater than $1 / 8$ inch in diameter was rejected.

\section{GAMMA SCINTILLATION COUNTING}

A gamma scintillation counting technique was used to determine the U-235 content of the ALPR core blanks. The details of this technique and its application to ALPR core blanks are described in detail in ANL-5944. (2) The $\mathrm{U}-235$ content could be determined to $\pm 0.1 \mathrm{gram}$ in the core blanks. 


\section{REFERENCES}

1. W. N. Beck and W. J. McGonnagle, "Development of Ultrasonic Techniques for Inspecting Experimental Boiling Water Reactor Cast Uranium Alloy Cores and Fuel Plates," ANL-5653 (December 1957).

2. W. J. McGonnagle and R. B. Perry, "Analysis of Fuel Element Core Blanks for Argonne Low Power Reactor by Gamma Counting," ANL-5944 (to be issued). 